\section{Arif Wicaksono}

Mahasiswa Magister Ilmu Pemerintahan Universitas Muhammadiyah Yogyakarta Email: arifwicaksono@gmail.com

\section{Suranto}

Dosen Magister IImu Pemerintahan Universitas Muhammadiyah Yogyakarta Email: suranto_umy@yahoo.com

http://dx.doi.org/10.18196/

igpp.2014.0004

\section{Optimalisasi Kinerja} Lembaga Ombudsman Daerah Istimewa Yogyakarta Dalam Penyadaran Hak Masyarakat Atas Pelayanan Publik

\begin{abstract}
The Ombudsman Institution is an independent institution which functions to supervise the public service performance issues. The existence of this institution is considered important to increase the public service especially for the public service performance by the government or local government and its existence is guaranteed by law. Ombudsman in its progress reaches the provincial level and the This research uses the qualitative research method. The data gathered including the primary and secondary data. The primary data covers interview and observation data, meanwhile secondary data covers literature data and documentation. The analysis unit of this research is the Ombudsman Institution of Yogyakarta Special Region with the interviewed research subjects such as the Head, Institution Representative, Socialization, Cooperation, and Networking Unit, and Socialization Executive Assistant. The finding of this research shows that the establishment of The Governor Regulation Number 69 Year 2014 about the Organization and Working Procedure of the Ombudsman Institution of Yogyakarta Special Region causes the incorporation of 2 institutions, The Regional Ombudsman Institution (LOD) and the Private Ombudsman Institution (LOS), to be a single institution called as the Ombudsman Institution of Yogyakarta Special Region and it was started in 2015. The Ombudsman Institution of Yogyakarta Special Region performance optimization has been seen in its achievements which are in accordance with the applicable regulations. The optimization of socialization task on public right awareness toward public service done by the Ombudsman Institution of Yogyakarta Special Region is considered good and optimum. It can be seen from the programs done in the socialization intensity, socialization quality, and socialization portion compared to other activities. The factors influencing the Ombudsman Institution of Yogyakarta Special Region performance in doing its duties covering the executive human resources factor, facilities and infrastructure and public participation.

Keywords: Ombudsman, Public Service, Performance, Socialization, Right Awareness.
\end{abstract}

\begin{abstract}
ABSTRAK
Lembaga Ombudsman merupakan lembaga Independen yang berfungsi untuk melakukan pengawasan terhadap persolan penyelenggaraan pelayanan publik. Kehadiran lembaga ini dirasa penting untuk meningkatkan pelayanan publik, terutama untuk penyelenggaraan pelayanan publik oleh pemerintah atau pemerintah daerah dan keberadaannya dijamin oleh Undang-Undang. Ombudsman dalam perkembangannya berada sampai level propinsi dan secara bertahap kelembagaan ombudsman dibentuk di daerah-daerah, termasuk di Daerah Istimewa Yogyakarta. Penelitian ini menggunakan metode penelitian kualitatif. Data yang dikumpulkan meliputi data primer dan data sekunder. Data primer meliputi data wawancara dan data observasi, sedangkan data sekunder meliputi data kepustakaan dan dokumentasi. Unit analisis dari penelitian ini adalah Lembaga Ombudsman DIY dengan subyek penelitian yang diwawancarai adalah ketua, wakil lembaga, bagian sosialisasi, kerjasama dan penguatan jaringan, assisten pelaksana bidang sosialisasi. Hasil penelitian ini menunjukkan bahwa terbitnya Peraturan Gubernur No. 69 Tahun 2014 tentang Organisasi dan Tata
\end{abstract}


Kerja LO DIY mengakibatkan terjadi penggabungan 2 kelembagaan yaitu Lembaga Ombudsman Daerah (LOD) dan Lembaga Ombudsman Swasta (LOS) ini menjadi satu kelembagaan yaitu LO DIY dan mulai dilaksanakan tahun 2015. Optimalisasi kinerja LO DIY dalam pelaksanaan tugasnya sudah terlihat dari pencapaian-pencapaian yang ada serta sesuai dengan peraturan yang ada. Optimalisasi tugas sosialisasi penyadaran hak masyarakat atas pelayanan publik yang di lakukan LO DIY dinilai berhasil dan sudah optimal. Hal ini dapat dilihat dari program-program yang dilakukan, dari intensitas sosialisasi, dari kualitas sosialisasi dan porsi sosialisasi dibanding kegiatan lainnya. Faktor-faktor yang mempengaruhi kinerja LO DIY dalam menjalankan tugasnya, meliputi: factor SDM pelaksananya, Sarana dan Prasarana serta partisipasi masyarakat.

Kata Kunci: Ombudsman, Pelayanan Publik, Kinerja, Sosialisasi, Penyadaran Hak.

\section{PENDAHULUAN}

Pemerintah mulai sadar akan perlunya lembaga Ombudsman di Indonesia menyusul adanya tuntutan masyarakat yang amat kuat untuk mewujudkan pemerintah yang bersih dan penyelenggaraan negara yang baik atau clean and good governance. Sehingga dibentuklah lembaga ini atas dasar Undang-Undang Nomor 37 Tahun 2008 tentang Ombudsman Republik Indonesia yang disahkan dalam Rapat Paripurna DPR RI pada tanggal 9 September 2008. Kemudian setahun berikutnya, keberadaan lembaga Ombudsman ini diperkuat dengan UU No. 25 Tahun 2009 tentang Pelayanan Publik.

Sebelum reformasi penyelenggaraan negara dan pemerintahan diwarnai dengan praktek Maladministrasi antara lain terjadinya korupsi, kolusi, dan nepotisme sehingga mutlak diperlukan reformasi birokrasi penyelenggaraan negara dan pemerintahan demi terwujudnya penyelenggaraan negara dan pemerintahan yang efektif dan efisien, jujur, bersih, terbuka serta bebas dari korupsi, kolusi, dan nepotisme. Pengawasan internal yang dilakukan oleh pemerintah sendiri dalam implementasinya ternyata tidak memenuhi harapan masyarakat, baik dari sisi obyektifitas maupun akuntabilitasnya.

Untuk lebih mengoptimalkan fungsi, tugas, dan wewenang Komisi Ombudsman Nasional, perlu dibentuk Undang-Undang tentang Ombudsman Republik Indonesia sebagai landasan hukum yang lebih jelas dan kuat. Hal ini sesuai pula dengan amanat Ketetapan Majelis Permusyawaratan Rakyat Nomor VIII/MPR/2001 
tentang Rekomendasi Arah Kebijakan Pemberantasan dan Pencegahan Korupsi, Kolusi, dan Nepotisme yang salah satunya memerintahkan dibentuknya Ombudsman dengan undang-undang. Maka lahirlah Undang-Undang No. 37 Tahun 2008 Tentang Ombudsman Republik Indonesia.

Dalam perkembangnya Ombudsman Republik Indonesia (ORI) mempunyai perwakilan-perwakilan di setiap propinsi di seluruh Indonesia yang didirikan secara bertahap sesuai kemampuan keuangan negara. Pembentukan Ombudsman Republik Indonesia di tingkat daerah bertujuan mendekatkan pelayanan Ombudsman kepada masyarakat luas. Peran pokok Ombudsman adalah menangani keluhan masyarakat, menyangkut keputusan atau tindakan administrasi pemerintahan dan pelayanan umum, melindungi orang dari pelanggaran hak, penyalahgunaan kekuasaan, kesalahan, pengabaian, keputusan yang tidak adil dan kesalahan administratif. Pembentukan kantor perwakilan ini tentu saja dengan tujuan untuk mendekatkan fungsi ombudsman sebagai lembaga pengawasan pelayanan publik kepada masyarakat di daerah-daerah. Hal ini tidak terkecuali bahwa Lembaga Ombudsman Republik Indonesia juga mempunyai perwakilan di Daerah Istimewa Yogyakarta.

LOD DIY dengan segala tugas dan wewenangnya, serta kendala dan hambatan yang ada seharusnya masih perlu melakukan optimalisasi kinerja ombudsman terhadap penyadaran hak-hak masyarakat atas pelayanan publik yang diterima. Hal ini penting dilakukan karena akan meningkatkan partisipasi publik DIY dalam melakukan pengawasan terhadap penyelenggaraan pelayanan publik sehingga dari lembaga penyelenggara pelayanan publik dengan sendirinya akan melakukan peningkatan pelayanan dan menghormati hak-hak masyarakat dalam pelayanan publik.

Berdasarkan latar belakang masalah, maka dapat dirumuskan masalah dalam penelitian ini adalah: 
1. Bagaimana Lembaga Ombudsman DIY menjalankan tupoksinya sebagai lembaga yang menangani masalah pelayanan publik di DIY?

2. Bagaimana optimalisasi kinerja Lembaga Ombudsman DIY dalam penyadaran hak masyarakat atas pelayanan publik di DIY?

3. Faktor-faktor apa yang mempengaruhi optimalisasi kinerja Lembaga Ombudsman DIY dalam peningkatan pelayanan publik di DIY?

\section{KERANGKA TEORI}

Penelitian tentang Lembaga Ombudsman sebagai lembaga pengawasan pelayanan publik telah beberapa kali dilakukan, baik dari sudut pandang Ilmu Administrasi Negara, Administrasi Publik, Ilmu Hukum, atau ilmu sosial lainnya. Oleh karena itu untuk mengawali penelitian ini, ada beberapa kajian pustaka yang relevan dengan tema penelitian. Hal ini penting untuk mengambil entry point penelitian, positioning penelitian serta perbedaan dengan penelitian terdahulu.

Kebanyakan penelitian selama ini fokusnya lebih kepada fungsi pengawasan dan penyelesaian masalah yang merupakan tugas pokok dari LOD. Penelitian yang dilakukan peneliti memberikan sudut pandang yang berbeda, peneliti akan melihat kinerja LOD DIY ini terkait optimalisasi kinerja dalam hal penyadaran hak masyarakat atas hak-hak dalam pelayanan publik di DIY.

Untuk mengkaji hal tersebut, peneliti secara teoritik mengkaji tentang konsep-konsep Optimalisasi, konsep organisasi publik, kinerja organisasi publik, pelayanan publik, konsep ombudsman, dan konsep penyadaran hak atas pelayanan publik. Konsep-konsep tersebut menjadi rangkaian kerangka teoritis yang digunakan untuk membedah permasalahan dalam penelitian ini.

Menurut Winardi (1999: 363) Optimal adalah ukuran yang menyebabkan tercapainya tujuan sedangkan jika dipandang dari 
sudut usaha, Optimalisasi adalah usaha memaksimalkan kegiatan sehingga mewujudkan keuntungan yang diinginkan atau dikehendaki. Dari uraian tersebut diketahui bahwa optimalisasi merupakan suatu proses yang dilakukan dengan cara terbaik dalam suatu pekerjaan untuk mendapatkan keuntungan tanpa mengurangi kualitas pekerjaan. Optimalisasi hanya dapat diwujudkan apabila dalam pewujudannya secara efektif dan efisien. Dalam penyelenggaraan organisasi, senantiasa tujuan diarahkan untuk mencapai hasil secara efektif dan efisien agar optimal.

Organisasi publik sering dilihat pada bentuk organisasi pemerintah yang dikenal sebagai birokrasi pemerintah (organisasi pemerintahan). Menurut Prof. Dr. Taliziduhu Ndraha Organisasi publik adalah organisasi yang didirikan untuk memenuhi kebutuhan msyarakat akan jasa publik dan layanan civil. Organisasi publik adalah organisasi yang terbesar yang mewadahi seluruh lapisan masyarakat dengan ruang lingkup Negara dan mempunyai kewenangan yang absah (terlegitimasi) di bidang politik, administrasi pemerintahan, dan hukum secara terlembaga sehingga mempunyai kewajiban melindungi warga negaranya, dan melayani keperluannya, sebaliknya berhak pula memungut pajak untuk pendanaan, serta menjatuhkan hukuman sebagai sanksi penegakan peraturan. (Ndraha, 2005: 18).

Menurut Steers pengertian kinerja organisasi adalah tingkat yang menunjukan seberapa jauh pelaksanaan tugas dapat dijalankan secara aktual dan misi organisasi tercapai (Steers, 2003:67). Dari definisi tersebut, dapat dipahami bahwa kinerja organisasi adalah seberapa jauh tingkat kemampuan pelaksanaan tugas-tugas organisasi dalam rangka pencapaian tujuan sesuai dengan kemampuan yang dimiliki dan program/kebijakan/visi dan misi yang telah ditetapkan sebelumnya. Pengertian Kinerja dalam organisasi merupakan jawaban dari berhasil atau tidaknya tujuan organisasi yang telah ditetapkan. Para instansi sering tidak memperhatikan kinerja instansi 
atau organisasi kecuali kinerja sudah amat buruk.

Pelayanan publik adalah kegiatan atau rangkaian kegiatan dalam rangka pemenuhan kebutuhan pelayanan sesuai dengan peraturan perundang-undangan bagi setiap warga negara dan penduduk atas barang, jasa, dan/atau pelayanan administratif yang disediakan oleh penyelenggara pelayanan publik (UU No. 25 Tahun 2009 tentang Pelayanan Publik). Sedangkan menurut Agung Kurniawan (Pasalong, 2007:135) pelayanan publik adalah pemberian pelayanan (melayani) keperluan orang lain atau masyarakat yang mempunyai kepentingan pada organisasi itu sesuai dengan aturan pokok dan tata cara yang telah ditetapkan. Subarsono seperti yang dikutip oleh Agus Dwiyanto (2005:141) pelayanan publik didefinisikan sebagai serangkaian aktivitas yang dilakukan oleh birokrasi publik untuk memenuhi kebutuhan warga pengguna.

Menurut Gaster (1996) ada tiga argumen bagi pemerintah untuk mempromosikan kebijakan kualitas dalam pelayanan publiknya. Pertama, kebijakan kualitas menguat di pemerintahan lokal disebabkan adanya desakan dari eksternal. Kedua, kebijakan kualitas akan memberikan kontribusi terhadap popularitas dan keberlangsungan dari pemerintah lokal. Ketiga, Kebijakan kualitas dapat membawa pemerintah lokal dan masyarakatnya lebih dekat dan fokus pada konsumen atau citizen sehingga menjadi baseline bagi pelayanan publik dan nilai-nilai demokratik.

Definisi Ombudsman secara kontemporer yang cukup relevan dengan perkembangan Ombudsman modern pada masa sekarang ini, seperti Pope $(2003,158)$ mengemukakan bahwa ombudsman adalah sebuah jabatan yang secara independen menampung dan memeriksa pengaduan mengenai pelayanan administrasi publik. Menurut Rosenbloom dan Kravcuk (2002: 496) ombudsman adalah lembaga bentukan legislatif yang bersifat independen, yang diberikan wewenang untuk menyelidiki keluhan-keluhan yang bersifat khusus dari individu warga masyarakat berkenaan dengan tindak 
maladministrasi yang dilakukan pemerintah.

Menurut UU No. 37 Tahun 2008 tentang Ombudsman Republik Indonesia menyebutkan bahwa Ombudsman Republik Indonesia yang selanjutnya disebut Ombudsman adalah lembaga negara yang mempunyai kewenangan mengawasi penyelenggaraan pelayanan publik baik yang diselenggarakan oleh penyelenggara negara dan pemerintahan termasuk yang diselenggarakan oleh Badan Usaha Milik Negara, Badan Usaha Milik Daerah, dan Badan Hukum Milik Negara serta badan swasta atau perseorangan yang diberi tugas menyelenggarakan pelayanan publik tertentu yang sebagian atau seluruh dananya bersumber dari anggaran pendapatan dan belanja negara dan/atau anggaran pendapatan dan belanja daerah.

Tetapi sesungguhnya ombudsman tidak sekedar sebuah sistem untuk menyelesaikan keluhan masyarakat kasus demi kasus, yang utama mengambil inisiatif untuk mengkhususkan perbaikan administratif atau sistemik dalam upayanya meningkatkan mutu pelayanan masyarakat. Maladministrasi adalah perbuatan koruptif yang meskipun tidak menimbulkan kerugian negara, namun mengakibatkan kerugian bagi masyarakat (warga negara dan penduduk) karena tidak mendapatkan pelayanan publik yang baik (mudah, murah, cepat, tepat dan berkualitas).

Penyadaran (kesadaran) menurut Kamus Bahasa Indonesia adalah proses membuat orang sadar, dalam arti membuat sadar akan sesuatu. Dalam Cambridge International Dictionary of English (1995) ada sejumlah definisi tentang kesadaran. Pertama, kesadaran diartikan sebagai kondisi terjaga atau mampu mengerti apa yang sedang terjadi. Kedua, kesadaran diartikan sebagai semua ide, perasaan, pendapat, dan sebagainya yang dimiliki seseorang atau sekelompok orang. Selain itu kesadaran diartikan sebagai pemahaman atau pengetahuan seseorang tentang dirinya dan keberadaan dirinya.

Sebagaimana yang dikemukakan oleh Widjaja (1984:46) menyatakan bahwa "Kita sadar jika kita tahu, mengerti, insyaf dan 
yakin tentang kondisi tertentu”. Kesadaran masyarakat lahir dari masyarakatnya itu sendiri yang lahir dari kebiasaaan dalam masyarakat, dipengaruhi oleh lingkungan, peraturan-peraturan dan peranan pemerintahnya. Sedangkan hak adalah segala sesuatu yang harus di dapatkan oleh setiap orang yang telah ada sejak lahir atau bahkan sebelum lahir. Di dalam Kamus Bahasa Indonesia hak memiliki pengertian tentang sesuatu hal yang benar, milik, kepunyaan, kewenangan, kekuasaan untuk berbuat sesuatu (karena telah ditentukan oleh undang-undang, aturan, dan sebagainya), kekuasaan yang benar atas sesuatu atau untuk menuntut sesuatu, derajat atau martabat. Penyadaran hak dalam hal ini adalah proses membuat orang sadar, orang tahu, orang paham dan mengerti tentang segala sesuatu yang harus mereka dapatkan berdasarkan ketentuan atau aturan yang ada.

Berdasarkan pengertian di atas, dapat disimpulkan bahwa penyadaran hak adalah memberikan pengertian, pemahaman dan mengajak untuk sadar seseorang atau masyarakat terhadap hal-hal yang menjadi kepunyaannya, kewenangannya atau hal yang harus didapatnya. Konsep ini intinya mengajak orang atau kelompok orang untuk menyadari hak (sesuatu yang seharusnya menjadi miliknya) agar mereka dapat bersikap dan bertindak sesuai dengan hak tersebut.

Dalam konteks pelayanan publik, hak masyarakat terhadap pelayanan publik dapat dilihat dalam UU No. 25 tahun 2009 tentang Pelayanan Publik, Pasal 18 menyebutkan bahwa hak masyarakat adalah:

a. Mengetahui kebenaran isi standar pelayanan;

b. Mengawasi pelaksanaan standar pelayanan;

c. Mendapat tanggapan terhadap pengaduan yang diajukan;

d. Mendapat advokasi, perlindungan, dan/atau pemenuhan pelayanan;

e. Memberitahukan kepada pimpinan penyelenggara untuk 
memperbaiki pelayanan apabila pelayanan yang diberikan tidak sesuai dengan standar pelayanan;

f. Memberitahukan kepada pelaksana untuk memperbaiki pelayanan apabila pelayanan yang diberikan tidak sesuai dengan standar pelayanan;

g. Mengadukan pelaksana yang melakukan penyimpangan standar pelayanan dan/atau tidak memperbaiki pelayanan kepada penyelenggara dan ombudsman;

h. Mengadukan penyelenggara yang melakukan penyimpangan standar pelayanan dan/atau tidak memperbaiki pelayanan kepada Pembina penyelenggara dan ombudsman; dan

i. Mendapat pelayanan yang berkualitas sesuai dengan asas dan tujuan pelayanan.

Secara sederhana dapat dijelaskan bahwa LOD DIY mempunyai kinerja yang dijabarkan dengan tugas-tugasnya, diantara tugas-tugas tersebut ada 2 yang terkait dengan penyadaran hak masyarakat atas pelayanan publik. Tugas tersebut adalah menyebarluaskan pemahaman mengenai kedudukan, fungsi, tugas, wewenang, dan program kerja ombudsman daerah kepada masyarakat dan tugas melakukan koordinasi dan kerjasama dengan berbagai lembaga baik pemerintah maupun swasta (biasanya terkait sosialisasi). Apakah dalam menjalankan fungsi tersebut dapat dikategorikan optimal atau tidak, maka penelitian ini akan mengkajinya.

\section{METODE PENELITIAN}

Dalam penelitian ini digunakan metode penelitian kualitatif. Konsep penelitian kualitatif sebenarnya menunjuk dan menekankan pada proses, dan berarti tidak diteliti secara ketat atau terukur (jika memang dapat diukur), dilihat dari kualitas, jumlah, intensitas atau frekuensi. Secara spesifik penelitian kualitatif ini menggunakan pendekatan deskriptif, dimana peneliti berusaha mendeskripsi-kan 
suatu fenomena yang terjadi secara utuh dan sistematis. Penelitian ini dilakukan di Lembaga Ombudsman Daerah DIY, yaitu yang beralamat di Jl. Wolter Mongonsidi No. 20, Karangwaru, Tegalrejo Yogyakarta.

Unit analisis dari penalitian ini adalah Lembaga Ombudsman Daerah DIY (LOD DIY). Unit analisis berupa lembaga bukan perorangan, namun yang akan diwawancarai adalah orang-orang (narasumber) yang mempunyai peran penting dalam lembaga tersebut, misalkan pimpinan, asisten, humas, pelaku, atau bagian tertentu yang ditugasi dalam urusan sosialisasi. Narasumber dalam penelitian ini direncanakan ketua LOD DIY sebagai wakil lembaga, Wakil ketua, bagian sosialisasi, kerjasama dan penguatan jaringan, assisten pelaksana, bagian kesekretariatan, pelaksana teknis dan pegawai-pegawai yang tahu betul atau terlibat dalam hal sosialisasi lembaga ombudsman dan upaya penyadaran hak masyarakat atas pelayanan publik. Data yang dikumpulkan dalam penelitian ini meliputi data primer dan data sekunder. Peneliti menggunakan teknik pengumpulan data melalui Observasi, Wawancara mendalam dan dokumentasi

Analisa dan interpretasi data mengunakan metode penelitian deskriptif (kualitatif) dilakukan dengan cara: Peringkasan data (reduksi data) dimana data mentah diseleksi, disederhanakan, dan diambil intinya. Data disajikan secara tertulis berdasarkan kasuskasus faktual yang saling berkaitan. Menjabarkan dan menghubungkan proposisi-proposisi yang muncul dari data. Menarik kesimpulan (verifikasi data) atau pola keteraturan/pola penyimpangan yang terjadi dalam fenomena-fenomena tersebut, membuat prediksi atas kemungkinan perkembangan selanjutnya.

\section{PEMBAHASAN}

Pelayanan publik di DIY lebih mendalam dapat dilihat dari bagaimana dukungan kebijakan dan peraturan-peraturan daerah 
untuk melakukan peningkatan publik. Selanjutnya bagaimana implementasinya selama ini serta bagaimana tanggapan masyarakat terhadap pelayanan publik di DIY secara umum. Pembahasan ini akan mampu memberikan gambaran deskriptif tentang pelayanan publik di DIY.

Peraturan yang telah ada di DIY terkait pelayanan publik, berikut adalah beberapa peraturan gubernur dan perda yang teridentifikasi sebagai peraturan yang mendukung kebijakan pelayanan publik di DIY: (diolah dari berbagai sumber)

1. Peraturan Gubernur Daerah Istimewa Yogyakarta Nomor 33 Tahun 2012 Tentang Standar Pelayanan Publik Bagi Satuan Organisasai Perangkat Daerah.

2. Peraturan Daerah Daerah Istimewa Yogyakarta Nomor 5 tahun 2014 tentang Pelayanan Publik.

3. Peraturan Daerah Kota Yogyakarta Nomor 7 Tahun 2011 Tentang Penyelenggaraan Pelayanan Publik

4. Peraturan Daerah Kabupaten Bantul Nomor 02 Tahun 2014 Tentang Penyelenggaraan Pelayanan Publik

Kemudian kabupaten yang lain seperti Sleman, Kulonprogo dan Gunungkidul saat ini sedang mempersiapkan untuk menuju ke sana. Namun demikian, tidak berarti mereka tidak melakukan apa-apa. Kegiatan penataan secara organisasi daerah terus dilakukan guna memenuhi tuntutan masyarakat atas pelayanan publik yang ada. Secara parsial dan sektoral mereka juga melakukan hal yang sama dalam rangka mendukung pelaksanaan pelayanan publik dilingkungan tempat kerjanya. Peraturan-peraturan pada level Peraturan Bupati, Peraturan Kepala Dinas atau Surat-Surat Keputusan telah banyak dibuat guna menuju pelayanan yang prima dan berkualitas.

Selain dari peraturan yang ada, arah kebijakan terkait dengan pelayanan publik bisa dilihat dari dokumen-dokumen perencanaan strategis atau Road Map yang ada. Misalnya terdapat Dokumen Road Map Reformasi Birokrasi Pemerintah Daerah DIY 2012 - 2017 oleh 
Tim Reformasi Birokrasi Pemerintah Daerah DIY, yang agendanya adalah melakukan penataan menyeluruh terhadap kebijakan dan implementasi dari lembaga dan pegawai untuk maksud peningkatan pelayanan publik. Pemerintah DIY sangat paham, bahwa inti dari pelayanan adalah pada manusianya, pada SDMnya dan pada kelembagaannya.

Terkait dengan implemantasi kebijakan pelayanan publik di DIY dapat kita lihat dari berbagai kegiatan-kegiatan yang telah terlaksana baik pada level DIY maupun pada level kegiatan kabupaten/kota atau pada level Satuan Kerja Pemerintah Daerah (SKPD) atau bahkan pada Unit Pelaksana Teknis Daerah UPTD. Implementasi ini secara umum dapat dilihat dari pencapaian prestasi, berita-berita inovasi pelayanan publik atau juga pada dokumen-dokumen riset atau penilaian lembaga lain yang ada.

Upaya reformasi birokrasi yang selalu menyertai proses penyelenggaraan pemerintahan Daerah Istimewa Yogyakarta, meskipun telah mencapai berbagai prestasi keberhasilan, semakin menemukan relevansinya dengan telah ditetapkannya Undang-undang Nomor 13 Tahun 2012 tentang Keistimewaan Daerah Istimewa Yogyakarta. Implementasi undang-undang dimaksud berdampak sangat signifikan terhadap penyelenggaraan pemerintahan di Daerah Istimewa Yogyakarta ke depan. Amanat tujuan keistimewaan dan atribusi tambahan kewenangan keistimewaan yang ada di dalamnya menjadi kekuatan pendorong (driving force) bagi jajaran Pemerintah Daerah DIY untuk menata diri semakin lebih baik lagi.

\section{OPTIMALISASI KINERJA LEMBAGA OMBUDSMAN DIY}

Optimalisasi kinerja LO DIY dapat diuraikan berdasarkan bagimana tugas LO DIY ini dilaksanakan. Adapun fokus penelitian ini adalah pelaksanaan tugas pada periode tahun 2012 - 2014. Berikut adalah penjabarannya:

A. MENYUSUN PROGRAM KERJA LEMBAGA OMBUDSMAN. 
Menyusun program kerja merupakan kegiatan yang harus dilakukan komisioner pada awal masa jabatannya. Program yang dimaksud adalah program-program yang direncanakan akan dilakukan dalam masa jabatannya ke depan. Penyusunan program ini dilakukan berdasarkan fungsi, tugas dan tujuan dari kelembagaan LO. Program kerja diturunkan dari rencana strategis dan setiap tahun dilakukan penetapan prioritas program yang terkait dengan penggunaan anggaran yang direncanakan atau yang tersedia.

Ada 3 bidang pokok dalam struktur kerja LO DIY yaitu pada bidang Penanganan Laporan, Bidang Penelitian dan Pengembangan, serta Bidang Sosialisasi dan Penguatan Jaringan. Pada bidang penanganan laporan, dari tahun 2012 sampai tahun 2014 terlihat programnya masing-masing ada 4 program. Meskipun demikian, nama-nama programnya tidak selalu sama. Hal ini disesuaikan dengan kondisi masyarakat, kondisi kelembagaan dan kondisi wacana pelayanan publik yang ada. Program yang pokok ada adalah penanganan laporan atau tindak lanjut laporan. Hal ini merupakan pelaksanaan fungsi pengawasan dan tugas melakukan tindak lanjut laporan masyarakat.

Pada bidang sosialisasi, pada tahun 2012 jumlah program ada 10 program, tahun 2013 ada 4 program, dan pada tahun 2014 ada 3 program. Jumlah program memang terjadi penuruan drastis, namun secara kualitas pelaksanaan program ini ditingkatkan. Selain yang tertulis dara rencana program, banyak program sosialisasi yang tidak tertulis yang dikarenakan adanya program-program yang menempel pada bidang-bidang yang lain. Selain itu juga ada sosialisasi yag sifatnya tidak biaya yang sifatnya massif yang dilakukan oleh seluruh pegawai LO DIY dalam berbagai kesempatan, baik untuk teman, tetangga, keluarga dan dimanapun mereka berada.

Tugas untuk menyusun perencanaan program kerja LO DIY telah dilaksanakan berdasarkan peraturan yang ada. Terkait optimalisasi kinerja, penyusunan program kerja merupakan syarat kegiatan yang 
harus dilakukan untuk menunjang keberhasilan tugas-tugas yang lain. Perencanaan program LO DIY merupakan landasan pelaksanaan program kerja dan telah dilakukan oleh komisioner yang dibuktikan dengan adanya dokumen-dokumen perencanaan.

\section{B. MENYEBARLUASKAN PEMAHAMAN MENGENAI KEDUDUKAN, FUNGSI, TUGAS, WEWENANG, DAN PROGRAM KERJA LO DIY KEPADA SELURUH MASYARAKAT.}

Tugas dari LO DIY yang lain yang tidak kalah penting dari penanganan laporan pelanggaran pelayanan publik adalah sosialisasi terkait dengan posisi, fungsi, tugas danwewenang kelembagaan LO DIY dan upaya penyadaran hak-hak publik atas pelayanan publik. Tugas ini meliputi penyadaran hak, pengenalan keberadan lembaga Ombudsman termasuk peran dan fungsinya, serta bagaimana pelayanan publik yang seharusnya diterima oleh masyarakat. Pengetahuan ini merupakan awal dari keberanian masyarakat untuk menyuarakan pelanggaran atau ketidakpuasan pelayanan publik yang mereka terima. Artinya sistem pelaporan tidak akan berjalan optimal jika masyarakat tidak ada yang melapor karena ketidaktahuan akan hak-hak publiknya serta tidak tahu ada lembaga tempat mereka pelapor atas pelanggaran pelayanan publik.

Menyebarluaskan artinya melakukan sosialisasi, dan bidang yang berkaitan langsung dengan tugas ini adalah kelompok bidang sosialisasi, kerjasama dan penguatan jaringan. Secara garis besar, program-program sosialisai yang telah dilaksanakan adalah: Sosialisasi melalui media Radio, Sosialisasi melalui Siaran TV, Sosialisasi langsung ke warga masyarakat, Sosialisasi dengan berbagai model.

1) Pembuatan Media Sosialisasi, berupa: leaflet dan kalender, bahan tayang/presentasi, banner dan lain-lain.

2) Penguatan jaringan dengan menghadiri undangan dari jejaring LOD DIY. Menghadiri undangan merupakan salah satu cara 
untuk mensosialisasikan LOD DIY dan memperkuat jaringan.

3) Sosialisasi melalui diskusi publik.

4) Sosialisasi melalui iklan layanan masyarakat. Pada Tahun 2012, LOD DIY bekerjasama dengan radio Global dan RRI untuk pembuatan Iklan Layanan Masyarakat.

Tugas untuk menyebarluaskan pemahaman mengenai kedudukan, fungsi, tugas, wewenang, dan program kerja LO DIY kepada seluruh masyarakat telah dilakukan oleh Komisioner LO DIY pada periode 2012 - 2014. Hal ini dibuktikan dengan dokumen kegiatan-kegiatan sosialisasi dengan berbagai modelnya. Program sosialisasi yang ada dalam perencanaan mampu dilaksanakan semua setiap tahunnya, sehingga dapat disimpulkan tugas ini secara kinerja dianggap tercapai dan sudah optimal.

\section{MELAKUKAN KOORDINASI DAN ATAU KERJASAMA DENGAN BERBAGAI LEMBAGA, BAIK PEMERINTAH MAUPUN SWASTA.}

Kerjasama yang dilakukan oleh LOD DIY untuk perbaikan pelayanan publik dilakukan dengan bekerjasama dengan Lembaga lain seperti Komisi Informasi Provinsi (KIP) DIY, Komisi Penyiaran Indonesia Daerah (KPID), Ombudsman Republik Indonesia (ORI) Perwakilan DIY-Jawa Tengah, dan Lembaga Ombudsman Swasta (LOS) DIY yaitu dengan menandatangani surat kerjasama tentang sinergisitas kelembagaan.

Tugas melakukan koordinasi dan atau kerjasama dengan berbagai lembaga, baik pemerintah maupun swasta secara nyata telah dilakukan oleh LO DIY dalam berbagai kesempatan yang ada. Berdasarkan dokumen, kegiatan ini telah dilaksanakan sesuai dengan peraturan yang ada. Oleh karena itu untuk tugas ini dapat dikatakan terlaksana dengan baik dan secara kinerja telah menunjukkan optimalisasi baik dari sisi kegiatan maupun sisi penggunaan anggaran. 
D. MENERIMA PENGADUAN DARI MASYARAKAT.

Fungsi LO DIY dalam Pergub no. 69 Tahun 2014 tentang Organisasi dan Tata Kerja LO DIY adalah sebagai lembaga pengawasan masyarakat terhadap penyelenggaraan pemerintahan daerah dan praktik dunia usaha. Oleh sebab itu tugas pokoknya adalah menerima laporan, pengaduan serta menindaklanjuti pelaporan tersebut dengan investigasi, mediasi, koordinasi dan rekomendasi. Tugas pokok ini merupakan prioritas daripada tugastugas yang lain seperti sosialisasi, penelitian dan kelembagan. Hal ini tidak lain karena kehadiran LO pada awalnya adalah untuk melakukan pengawasan dan penanganan masalah terkait pelayanan publik yang kurang baik.

Tugas menerima pengaduan dari masyarakat merupakan salah satu tugas pokok dari LO DIY. Berdasarkan dokumen yang ada, dapat disimpulkan sebagai lembaga penerima aduan masyarakat LO DIY sudah mampu melaksanakan tugas tersebut. Melalui berbagai bidang aduan, berbagai media pengaduan dan berbagai wilayah di DIY, maka dapat dikatakan tugas ini telah berjalan dengan baik. Optimalisasi kinerja dilakukan dengan penggunaan berbagai media pengaduan, baik itu datang langsung, melalui telepon, SMS Gateway, surat, kotak adauan, dan lain sebagainya.

\section{E. MENINDAK LANJUTI PENGADUAN DARI MASYARAKAT.}

Penanganan laporan di LOD DIY secara umum melalui tahap investigasi, klarifikasi dan/atau mediasi. Beberapa laporan dapat dinyatakan selesai dalam tahap mediasi dimana kedua belah pihak (Pelapor dan Terlapor) bersepakat untuk menyelesaikannya atau mengganggap permasalahan selesai dalam forum mediasi. Sementara penyelesaian beberapa laporan yang lain dapat berujung pada Pendapat Hukum LOD DIY, kesimpulan, dan/atau Rekomendasi LOD DIY.

Tugas menindaklanjuti laporan masyarakat dengan prosedur yang 
ada telah dilakukan oleh LO DIY sebagai lembaga pengawasan pelayanan publik. Berdasarkan laporan yang ada, kegiatan ini telah berjalan secara optimal dengan melihat kasus-kasus yang telah berhasil dipecahkan dan ditindaklanjuti, baik itu melalui mediasi maupun rekomendasi.

\section{F. MEMBUAT LAPORAN TRIWULANAN DAN TAHUNAN.}

Laporan pelaksanaan fungsi dan tugas dari LO DIY dilakukan triwulanan dan tahunan. Artinya dalam satu tahun ada lima laporan. Misal pada tahun 2012, laporan yang dikeluarkan adalah laporan triwulan I, II, III dan VI serta Laporan Tahunan 2012. Fungsi pelaporan ini adalah untuk melakukan control kegiatan setiap 3 bulan sekali. Selain itu control pencapaian atau realisasi program dan control penggunaan anggaran juga. Laporan wajib diserahkan kepada Gubernur sebagaimana amanat Pergub no 69 tahun 2014. Selain itu laporan juga dipublik melalui web site LO DIY yaitu www.lod-diy.or.id sebagai sarana keterbukaan publik. Dengan publisitas umum ini, diharapkan semua pihak dapat melakukan pengawasan, pemantauandan berpartisipasi aktif dalam tugas dan fungsi LO DIY.

\section{OPTIMALISASI PENYADARAN HAK MASYARAKAT ATAS PELAYANAN PUBLIK}

Penyadaran hak masyarakat atas pelayanan publik tidak lepas dari sosialisasi yang dilakukan oleh LO DIY. Bidang yang berkaitan langsung adalah bidang sosialiasasi, kerjasama dan penguatan jaringan. Karena sosialisasi yang dilaksanakan LO DIY selama ini adalah terkait dengan posisi, tujuan, fungsi, tugas, dan wewenang kelembagaan yang pada akhirnya mengajak kepada masyarakat untuk sadar akan hak-haknya dalam pelayanan publik. Sosialisasi temanya tidak bisa dipisahkan antara profil kelembagaan dengan penyadaran hak atas pelayanan publik. Untuk melihat optimalisasi kegiatan atau 
program-program yang dilakukan, paling tidak hal-hal yang ulas adalah program-program sosialisasi apa saja yang dilakukan selama ini, kemudian bagaimana intensitasnya, lalu bagaimana kualitas sosialisasinya dan terakhir bagaimana porsi kegiatan sosialisasi terhadap program-program yang lain.

\section{A. PROGRAM-PROGRAM SOSIALISASI YANG DILAKUKAN}

Program-program sosialisasi LO DIY yang dilakukan selama ini memang bervariasi. Ada yang modelnya rutin dilakukan setiap tahun, namun ada yang dilakukan pada jadwal yang tidak menentu. Hal ini disesuaikan dengan kebutuhan dan dengan anggaran yang ada. Berikut ini adalah program-program sosialisasi yang telah dilakukan LO DIY pada kurun waktu 2012 - 2014 adalah Program sosialisasi tidak berbiaya yang meliputi Sosialisasi yang dilakukan menempel pada program dibidang yang lain dan Sosialisasi yang dilakukan oleh semua pegawai, baik komisioner, asisten, maupun kesekretariatan secara mandiri terhadap lingkungannya, lingkungan keluarga, tetangga (RT), dan teman. Serta Program berbiaya berarti program tersebut masuk dalam program rencana kerja LO DIY. Program ini sudah direncanakan dalam satu tahun, dengan target yang sudah ditentukan dan disesuaikan dengan anggaran dan skala prioritas.

Melihat begitu banyaknya model sosialisasi yang dilakukan oleh LO DIY, maka secara program (variasi program) dalam sosialisasi dapat dikatakan optimal karena variasi program memungkinkan sosialisasi berjalan efektif karena dapat masuk kepada masyarakat umum secara luas. Optimal juga berarti efisien, dimana terkait juga dengan penggunaan sumber daya yang ada. Sosialisasi dapat diatakan efisien secara anggaran maupun secara SDM. Maka secara sederhana program-program sosialisasi yang ada menunjukkan optimalisasi kinerja dalam penyadaran hak masyarakat atas pelayanan publik. 


\section{B. INTENSITAS PROGRAM SOSIALISASI}

Intensitas artinya seberapa sering program-program tersebut dilaksanakan atau dilakukan. Artinya ada jumlah sekian kali setiap tahun program itu dilakukan. Berdasarkan intensitas sosialisasi yang ada, bahwa secara kuantitas atau intensitas terjadi penurunan setiap tahunnya, terutama untuk sosialisasi melalui media elektronik yaitu TV dan Radio. Hal ini di lakukan sosialisasi melalui media elektronik jam siarannya mahal, disamping itu masyarakat cenderung bosan dengan sosialisasi yang formatnya sama. Untuk pertemuan dengan warga secara langsung, pada tahun 2013 melaksanakan sebanyak 15 kali dari sebelumnya yang hanya 6 kali saja. Hal ini dilakukan karena dalam sosialisasi dengan warga terlaksana dengan lebih variatif dan sesuai dengan target sasaran serta tema yang cocok.

Berdasarkan paparan di atas dapat dikatakan secara intensitas program, kegiatan sosialisasi dalam berbagai model mengalami penurunan jumlah setiap tahunnya. Namun dalam hal ini intensitas tidak hanya dipahami setiap tahun, tetapi bisa juga dipahami dari periode jabatan komisioner selama 4 tahun. Apabila dilihat dalam kerangka satu periode, sosiaisasi dapat dikatakan cukup banyak intensitasnya. Dengan ketersediaan anggaran yang terbatas, sosialisasi mampu dilaksanakan sebanyak mungkin.

\section{KUALITAS PROGRAM SOSIALISASI}

Kualitas program sosialisasi sulit untuk diukur. Indikatorindikator kualitas sosialisasi sangat sulit ditentukan karena subyektifitas yang tinggi. Maka untuk melihat kualitas sosialisasi maka peneliti melihat pada dampaknya yang luas, akses publik yang mudah, segmen yang jelas, serta partisipasi publik yang tinggi. Berdasarkan criteria tersebut, maka jenis program sosialisasi yang berkualitas adalah: Sosialisasi melalui Website, Sosialisasi melalui TV dan Radio, Sosialisasi melalui pertemuan langsung dengan masyarakat, Sosialisasi melalui media cetak (rilis berita/artikel) 
Kualitas sosialisasi yang telah dilakukan dapat dinilau baik, optimal dan berhasil. Hal ini ditunjukkan dari tingkat partisipasi publik (pasif dan aktif) dalam setiap kegiatan LO DIY, sosialisasi mampu menjangkau luas semua kalangan masyarakat, serta sosialisasi telah ampu meningkatkan pelayanan publik dari penyelenggara pelayanan publik yang ada.

\section{PORSI PROGRAM SOSIALISASI DARI KESELURUHAN PROGRAM}

Porsi program sosialisasi dapat dilihat dari porsi program sosialisasi itu juga dapat dilihat dari porsi anggaran yang dianggarkan untuk kegiatan sosialisasi. Dalam penelitian ini, kedua pendekatan itu akan digunakan yaitu porsi berdasarkan kegiatan baik jumlah maupun kualitasnya, baik berbiaya maupun yang tidak berbiaya. Porsi yang kedua dengan pendekatan porsi anggaran, artinya melihat porsi tersebut dari besarnya anggaran yang dialokasikan untuk sosialisasi dibanding anggaran keseluruhan atau bidang-bidang lain.

Porsi kegiatan sosialisasi yang demikian dapat dikatakan besar, meskipun porsi anggaran relative kecil. Apabila jumlah kegiatan baik yang berbiaya (ber anggaran), menggunakan biaya bidang lain, dan sosialisasi melalui relawan serta pegawai digabung, maka porsi kegiatan sosialisasi sangat besar disbanding bidang lainnya. Oleh karena itu, dengan model seperti ini optimalisasi soasialisasi penyadaran hak atas pelayanan publik telah terwujud di LO DIY.

\section{E. FAKTOR-FAKTOR YANG MEMPENGARUHI OPTIMALISASI KINERJA LO DIY DALAM PENINGKATAN PELAYANAN PUBLIK DI DIY}

Mencari factor-faktor yang mempengaruhi kinerja LO DIY dalam peningkatan pelayanan publik di DIY tentu tidak mudah. Berangkat dari kendala dan hambatan serta hasil penelitian terkait kelebihankelebihan yang dimiliki LO DIY dalam melakukan tupoksinya diharapkan dapat menemukan factor-faktor tersebut. 


\section{FAKTOR PENGHAMBAT OPTIMALISASI KINERJA LO DIY}

a. Kendala internal. Pertama, adanya beberapa staf dan asisten yang mengajukan pengunduran diri.. Kedua, terkait dengan sarana prasarana yang ada yang masih kurang. Ketiga, padatnya perjalanan investigasi yang frekuensinya semakin tinggi sedang ketersediaan anggaran untuk perjalanan dinas terbatas dan masih banyak kendala teknis yang lain.

b. Kendala eksternal. Pertama, berlakunya UU ORI masih sering dipertanyakannya eksistensi LO DIY. Kedua, kendala dari luar misalnya terkait dengan anggaran di LOD DIY yang merupakan bagian dari Satuan Kerja Perangkat Daerah (SKPD) terkait yaitu Biro Hukum Setda DIY sehingga sistem keuangan dan pelaporannya pun meski sama persis dilakukan sebagaimana sistem SKPD terkait. Ketiga, ada sebagian kecil terlapor yang belum melaksanakan rekomendasi LOD DIY. Sedang LOD DIY tidak mempunyai kekuatan untuk memaksakan atas pelaksanaan rekomendasi tersebut.

c. Harapan yang belum tercapai.

Selain kendala yang masih ada, harapan ke depan terkait pelayanan publik di DIY dan kelembagaan LO DIY dapat menjadi acuan terkait kondisi ideal yang diharapkan dan sekaligus tentang faktor apa yang dipandang dapat mempengaruhi peningkatan kinerja LO DIY.

Kelembagaan LO DIY perlu kuat untuk mencapai hal ideal tersebut, maka untuk itu perlu adanya dukungan regulasi yang kuat, perlu dukungan anggaran yang proporsional dan perlu adanya sarana prasarana pendukung yang memadai (gedung dan kendaraan). Antara kendala dan harapan masih ada jarak yang harus dipenuhi, dan hal-hal ini dapat menjadi factor yang mempengaruhi kinerja LO DIY. 


\section{FAKTOR PENDUKUNG OPTIMALISASI KINERJA LO DIY}

Pada bagian ini, setelah melewati proses dan hasil dari analisis data yang panjang, setelah melihat kendala yang ada, dan setelah melihat harapan atau gambaran ideal LO DIY ke depan, dapat disimpulkan factor yang menjadi pengaruh. Dari pemetaan yang dilakukan, paling tidak ada 3 hal yang dapat dikatakan sebagai factor yang mempengaruhi kinerja LO DIY dalam rangka melakukan peningkatan pelayanan publik yang ada di DIY. Faktor-faktor tersebut adalah:

\section{A. FAKTOR SDM PELAKSANA}

Hal penting yang terungkap dalam penelitian ini terkait dengan optimalisasi sosialisasi LO DIY adalah faktor SDM pelaksananya. Mulai dari ketua, wakil ketua, komisioner, bagian administarsi atau kesekretariatan serta pegawai tetap lainnya. Dalam hal sosialisasi LO DIY semua SDM yang ada menjadi agen-agen sosialisasi yang tidak berbiaya. Sosialisasi dengan berbiaya juga berjalan dengan baik meskipun secara kuantitas diturunkan dari tahun ke tahun, namun secara kreatifitas dan secara kualitas ditingkatkan. Faktor SDM di LO DIY ini merupakan factor yang mempengaruhi keberhasilan dalam melaksanakan optimalisasi sosialisasi yang merupakan bagian dari kinerja LO DIY secara umum. Perpaduan kemampuan teknis, integritas, dan sikap mental positif, maka SDM menjadi kekuatan pokok dalam melakukan pekerjaan di LO DIY terutama dalam hal Sosialisasi penyadaran hak atas pelayanan publik di LO DIY.

\section{B. FAKTOR SARANA DAN PRASARANA}

Faktor sarana dan prasarana telah terungkap dalam penelitian ini. Dimana kebutuhan paling mendesak adalah kendaraan yang digunakan untuk mobile para pegawai dalam melakukan sosialisasi, investigasi dan keperluan tugas yang lain. Kebutuhan ini memang rasional, dimana jumlah struktur yang saat ini lebih besar 
memerlukan kendaraan yang lebih banyak. Ditambah juga lingkup pekerjaan antara pemerintahan daerah dan usaha swasta yang menjadi obyek pengawasan. Sarana prasarana khususnya kendaraan menjadi salah satu factor yang bisa mempengaruhi keberhasilan dan kualitas pelayanan LO DIY kepada masyarakat terkait tugas dan fungsinya, termasuk tugas sosialisasi.

\section{FAKTOR PARTISIPASI MASYARAKAT}

Partisipasi masyarakat dapat dijadikan salah satu factor yang mampu mempengaruhi optimalisasi pelaksanaan tugas dan fungsi LO DIY. Karena hanya dengan partisipasi masyarakat LO DIY dapat menjalankan fungsi dan tugasnya. Dalam fungsi pengawasan, membutuhkan partisipasi masyarakat untuk melaporkan jika ada yang melanggar. Dalam tugas sosialisasi, peran masyarakat sangat penting untuk ikut dalam sosialisasi untuk menjadi tahu, untuk menjadi berani menyampaikan temuan pelanggaran mal administrasi atau pelanggaran yang lain. Kemudian peran aktif lain dari masyarakat adalah untuk menjadi agen-agen informasi yang menyampaikan kepada masyarakat luas, atau mampu memberikan pendampingan terhadap tetangga, saudara, atau teman.

Faktor partisipasi masyarakat menjadi penting karena laporan paling banyak adalah dari masyarakat baik secara individu atau secara kelompok. Sedangkan investigasi atas prakasa sendiri porsinya masih sangat sedikit. Apabila tidak ada laporan masuk karena tidak adanya masyarakat yang melapor, sementara profil pelayanan publik di DIY masih dalam kondisi seperti ini, maka dapat dipastikan kerja LO DIY akan menjadi lebih berat karena harus mencari permasalahan pelayananpublik sendiri.

\section{KESIMPULAN}

Berdasarkan pembahasan dan proses penelitian yang dilakukan, paling tidak ada beberapa kesimpulan yang bisa disampaikan: 
1. Tugas untuk menyusun perencanaan program kerja LO DIY telah dilaksanakan berdasarkan peraturan yang ada. Tugas untuk menyebarluaskan pemahaman mengenai kedudukan, fungsi, tugas, wewenang, dan program kerja LO DIY kepada seluruh masyarakat telah dilakukan oleh Komisioner LO DIY pada periode 2012 - 2014. Hal ini dibuktikan dengan dokumen kegiatan-kegiatan sosialisasi dengan berbagai modelnya, sehingga dapat disimpulkan tugas ini secara kinerja dianggap tercapai dan sudah optimal. Tugas menerima pengaduan dari masyarakat merupakan salah satu tugas pokok dari LO DIY. Berdasarkan dokumen yang ada, dapat disimpulkan sebagai lembaga penerima aduan masyarakat LO DIY sudah mampu melaksanakan tugas tersebut. Optimalisasi kinerja dilakukan dengan penggunaan berbagai media pengaduan, baik itu datang langsung, melalui telepon, SMS Gateway, surat, kotak adauan, dan lain sebagainya.

2. Tugas menindaklanjuti laporan masyarakat dengan prosedur yang ada telah dilakukan oleh LO DIY sebagai lembaga pengawasan pelayanan publik. Berdasarkan laporan yang ada, kegiatan ini telah berjalan secara optimal dengan melihat kasus-kasus yang telah berhasil dipecahkan dan ditindaklanjuti, baik itu melalui mediasi maupun rekomendasi. Pelaporan sebagai bentuk tugas administratif sekaligus tugas untuk menunjukkan transparansi dan akuntabilitas publik selalu dilaksanakan baik triwulanan maupun tahunan. Pelaksanaan tugas ini telah berjalan dengan baik dan dilakukan secara tepat waktu dan dipublikasikan di websitenya yaitu www.lod-diy.or.id..

3. Optimalisasi sosialisasi penyadaran hak masyarakat atas pelayanan publik yang di lakukan LO DIY dinilai berhasil dan sudah optimal. Optimal dalam arti pelaksanaan dinilai efektif dan efisien. Hal ini bisa dilihat dari program-program sosialisasi yang dilaksanakan; intensitas sosialisasi yang banyak baik yang masuk 
100 dibiayai maupun yang tidak dibiayai; kualitas sosialisasi; dan porsi sosialisasi dibandingkan dengan program lainnya baik dipandang dari segi anggaran maupun dari segi kegiatan. Melihat begitu banyaknya model sosialisasi yang dilakukan oleh LO DIY, maka secara program (variasi program) dalam sosialisasi dapat dikatakan optimal karena variasi program memungkinkan sosialisasi berjalan efektif karena dapat masuk kepada masyarakat umum secara luas dan efisien secara anggaran maupun secara SDM.

4. Intensitas program sosialisasi apabila dipahami utuh dalam satu periode kepengurusan, karena memang kegiatan sosialisasi akan difokuskan atau diprioritaskan pada tahun pertama, tahun berikutnya lebih kepada tindak lanjut dan pengembangannya. Apabila dilihat dalam kerangka satu periode, sosiaisasi dapat dikatakan cukup banyak intensitasnya. Dengan ketersediaan anggaran yang terbatas, sosialisasi mampu dilaksanakan sebanyak mungkin. Kualitas sosialisasi yang telah dilakukan dapat dinilai baik, optimal dan berhasil. Hal ini ditunjukkan dari tingkat partisipasi publik (pasif dan aktif) dalam setiap kegiatan LO DIY, sosialisasi mampu menjangkau luas semua kalangan masyarakat, serta sosialisasi telah ampu meningkatkan pelayanan publik dari penyelenggara pelayanan publik yang ada. Porsi kegiatan sosialisasi dapat dikatakan besar, meskipun porsi anggaran relative kecil. Apabila jumlah kegiatan baik yang berbiaya (ber anggaran), menggunakan biaya bidang lain, dan sosialisasi melalui relawan serta pegawai digabung, maka porsi kegiatan sosialisasi sangat besar disbanding bidang lainnya. Oleh karena itu, dengan model seperti ini optimalisasi soasialisasi penyadaran hak atas pelayanan publik telah terwujud di LO DIY.

5. Faktor-faktor yang mempengaruhi kinerja LO DIY dalam menjalankan tugasnya, baik tugas pokoknya (menerima laporan dan tindak lanjutnya) maupun tugas sosialisasi dipengaruhi oleh 
beberapa factor pokok yaitu; factor SDM pelaksananya, Sarana dan Prasarana serta partisipasi masyarakat.

Berdasarkan hasil penelitian, maka saran yang bisa diberikan adalah:

1. Terkait dengan kelembagaan yang baru berdasarkan pergub no 56 tahun 2014, maka LO DIY perlu melakukan penyesuaianpenyesuaian baik secara administrative, kepemimpinan, budaya kerja, pembagian kerja serta estimasi yang teliti akan kebutuhan pendanaan, sarana prasarana, serta kebutuhan SDM untuk meningkatkan kinerjanya secara keseluruhan.

2. Terkait dengan metode sosialisasi, kedepan perlu diperbanyak dengan media-media online. Hal ini denga alasan masyarakat saat ini mulai berkembang ke sana dan secara biaya media online jauh lebih murah dan lebih luas jangkauannya.

3. Adanya rekomendasi yang seringkali tidak dilaksanakan oleh para terlapor. Sebaiknya selama proses rekomendasi diumumkan di media beserta monitoringnya. Hal ini bermaksud untuk memberikan sanksi sosial dan masyarakat bisa memantaunya.

4. Terkait dengan kelembagaan yang baru, perlu ada penelitian yang komprehensif terkait efektifitas kelembagaan LO DIY (satu lembaga) yang sekarang dibandingkan dengan LO DIY yang masa lalu (dua lembaga, LOD dan LOS).

\section{DAFTAR PUSTAKA}

Andari, Switi. 2012. Pelaksanaan Fungsi Lembaga Ombudsman Daerah Yogyakarta Dalam Rangka Mewujudkan Good Governance. Tesis: Magister Hukum UGM.

Cambridge International Dictionary of English. 1995. Oakleigh: Cambridge University Press.

Djahiri, A. Kosasih. 1985. Strategi Pengajaran Afektif Nilai Moral VCT Dan Games Dalam VCT, Bandung: Lab. PMP IKIP.

Dwiyanto, Agus. 2005. Mewujudkan Good Governance Melalui Pelayanan Publik, Yogyakarta: Gadjah Mada University Press. 
Dwiyanto, Agus. 2008. Reformasi Birokrasi Publik di Indonesia, Yogyakarta: Gadjah Mada University Press.

The Liang Gie. 1991. Pengantar filsafat ilmu, Yogyakarta: Liberty.

Handayani, Siti R. 2012. Kinerja Lembaga Ombudsman Daerah (LOD) Dalam Menyelesaikan Pengaduan Masyarakat Bidang Kesehatan Tahun 2008-2011 di DIY, Tesis, Magister Administrasi Publik UGM.

Hasibuan, Malayu S.P., Organisasi dan Motivasi. 1996. Jakarta: Bumi Aksara.

Hasibuan, Malayu S.P. 2004 Manajemen Sumber Daya Manusia. Cetakan ke Tujuh, edisi revisi, Jakarta: PT. Bumi Aksara.

Ibty, Idham. Keistimewaan Jogja Jamin Pelayanan Publik Secara Terpadu. 2012 Makalah disampaikan pada Seminar Raperda Pelayanan Publik DIY yang diselenggarakan oleh Lembaga Ombudsman Daerah Istimewa Yogyakarta.

Keban, Jeremias T., 2003. Enam Dimensi Strategis Administrasi Publik: Konsep, Teori dan Isu, Yogyakarta: Penerbit Gava Media.

Kemenpan RI. 2014. Top 99 Inovasi Pelayanan Publik Indonesia Tahun 2014, Jakarta: Pelangi Grafika.

Koemaruddin, Ensiklopedia Manajemen. 1991. Jakarta: Bumi Askara.

Lembaga Administrasi Negara (LAN) RI, Badan Pengawasan Keuangan dan Pembangunan (BPKP). 2000. Pengukuran Kinerja Instansi Pemerintah:Modul Sosialisasi Sistem Akuntabilitas Kinerja Istitut Pemerintah, Jakarta: Lembaga Administrasi Negara (LAN) Rl.

Mahmudi. 2005. Manajemen Kinerja Sektor Publik, Yogyakarta: Akademi Manajemen Perusahaan YKPN

Mahsun, Mohammad. 2013. Pengukuran Kinerja Sektor Publik, Edisi Pertama - Cetakan Keempat, Yogyakarta: BPFE Fakultas Ekonomi UGM.

Masduki, Teten. 2003 Ombudsman (Daerah) dan Pemberdayaannya dalam dalam Ombudsman Daerah, Mendorong Pemerintahan Yang Bersih, Kerjasama PUSHAM UII dengan Partnership Kemitraan dan Governance Reform in Indonesia.

Moleong, Lexy J. 2000. Metodologi Penelitian Kualitatif, Cetakan ke-13. Bandung: Remaja Rosdakarya.

Ndraha, Taliziduhu. 2005. Teori Budaya Organisasi, Jakarta: Rineka Cipta.

Pasolong, Harbani.2007. Teori Administrasi Publik, Bandung: ALFABETA.

Poerwadarminta WJS. 2002. Kamus Besar Bahasa Indonesia, Jakarta: Balai Pustaka.

Pope, Jeremy. 2003. Strategi Memberantas Korupsi: Elemen Sistem Integritas Nasional, terj. Masri Maris, edisi 1, Jakarta: Yayasan Obor Indonesia.

Putra, Indra P. 2014. Peran Ombudsman Republik Indonesia Perwakilan Provinsi Jawa Timur Dalam Penyelesaian Laporan Atas Dugaan Maladministrasi Penyelenggaraan Pelayanan Publik (Studi Kasus Penerimaan Peserta Didik Baru 2013 di Kota Surabaya, Skripsi, Jurusan Ilmu Administrasi Negara, Universitas Negeri Surabaya.

Robbins, SP and Judge. 2007. Organisasi Perilaku, Alih Bahasa Drs. Benjamin Molan, Jakarta: Salemba Empat.

Rosenbloom, David H., dan Robert S. Kravchuk. 2002. Public Administration: Under- 
standing Management, Politics, and Law in the Public Sector, New York: McGrawHill.

Salim, Agus (ed.). 2001. Teori dan Paradigma Penelitian Sosial, Yogyakarta: Tiara Wacana.

Sheila, Noor. 2014. Peran Perwakilan Lembaga Ombudsman Wilayah Provinsi Kaltim dalam Pengawasan Penyelenggaraan Pelayanan Publik, Skripsi, Program Studi IImu Administrasi Negara, Universitas Mulawarman.

Subarsono, AG. 2006. Analisis Kebijakan Publik: Konsep, Teori dan Aplikasi, Yogyakarta: Pustaka Pelajar.

Suhendra, Muhammad. 2014. Eksistensi Lembaga Ombudsman Dalam Pengawasan Penyelenggaraan Pelayanan Publik Di Provinsi Lampung, Tesis, Magister Hukum Universitas Lampung.

Sujata, Antonius, dan Surahman. 2002. Ombudsman Indonesia Di Tengah Ombudsman Internasional, Jakarta: Komisi Ombudsman Nasional.

Sujata, Antonius dkk. 2002. Ombudsman Indonesia Di Masa Lalu dan Masa Mendatang, Jakarta: Komisi Ombudsman Nasional.

Steers, Richard M. 2003. Efektivitas Organisasi, Terjemahan Magdalena Jamin, Jakarta: Erlangga.

Syamsi, Ibnu. 1994. Pokok-Pokok Organisasi dan Manajemen, Jakarta: Rineka Cipta. Syafiie, I. Kencana. 2006. Sistem Administrasi Negara, Jakarta: Bumi Aksara.

Thoha, Miftah. 2008. Birokrasi Pemerintahan Indonesia di Era Reformasi (Cet-2) Jakarta: Kencana.

Thoha, Miftah. 2008. Ilmu Administrasi Publik Kontemporer, Jakarta: Kencana.

Tjiptono, Fandy. 1998. Manajemen Jasa, Edisi 2, Yogyakarta: Penerbit Andi.

Triono, Agus. 2011. Pelaksanaan Fungsi Pengawasan Lembaga Ombudsman Daerah Dalam Mewujudkan Pemerintahan Yang Baik Di Provinsi Daerah Istimewa Yogyakarta, Tesis, Magister Hukum UGM.

Westra, Pariata. 1991. Ensiklopedia Administrasi, Jakarta: Gunung Agung, 1991.

Winardi. 1999. Pengantar tentang Teori Sistem dan Analisis Sistem, Bandung: Mandar Maju,

Wibowo. 2007. Manajemen Kinerja, Jakarta: PT Raja Grafindo Persada.

Widodo, Joko. 2001. Good Governance Telaah Dari Dimensi Akuntabilitas, Kontrol Birokrasi Pada Era Desentralisasi Dan Otonomi Daerah, Surabaya: Insan Cendekia.

Widjaja, A.W. 1984. Kesadaran Hukum Manusia dan Masyarakat Pancasila, Jakarta: Era Swasta.

\section{JURNAL}

Cahyani, Indah. 2011. "Penegakan Hukum Hak Konstitusional Warga Negara Indonesia Untuk Mendapatkan Pelayanan Publik Yang Baik Melalui Ombudsman Republik Indonesia (ORI)". Universitas Indonesia.

Hasjimzoem, Yusnani. 2013. "Eksistensi Ombudsman Republik Indonesia". Fiat Justisia Jurnal Ilmu Hukum Vol. 8 Nomor 2.

Muallidin, Isnaini. "Kebijakan Reorganisasi Perizinan untuk Meningkatkan Kualitas 
Pelayanan Publik di Kota Yogyakarta". Journal of Government and Politics: Volume 3 Nomor 1 Tahun Februari 2012.

Puruhito, Ghozali. 2013. "Peran Ombudsman Republik Indonesia Perwakilan Provinsi

Jawa Tengah dalam Peningkatan dan Perbaikan Pelayanan Publik". Universitas Diponegoro: www.undip.ac.id.

Sumber Lain:

Undang-Undang No. 37 Tahun 2008 tentang Ombudsman Republik Indonesia.

Undang-Undang No. 25 Tahun 2009 tentang Pelayanan Publik.

Undang- Undang No. 32 Tahun 2004 tentang Pemerintahan Daerah

Undang-Undang No. 23 Tahun 2014 tentang Pemerintahan Daerah.

Keputusan Menpan No: 63/KEP/M.PAN/7/2003 tentang Pedoman Umum

Penyelenggaraan Pelayanan Publik.

Peraturan Gubernur No. 21 Tahun 2008 tentang Organisasi dan Tata Kerja Ombudsman Daerah di Provinsi DIY.

Peraturan Gubernur No. 69 Tahun 2014 tentang Organisasi dan Tata Kerja Lembaga

Ombudsman DIY.

Surat Keputusan Gubernur No. 134 Tahun 2004 tentang Pembentukan dan Organisasi

Ombudsman Daerah di Provinsi DIY

Dokumen Road Map Reformasi Birokrasi Pemerintah Daerah DIY 2012 - 2017 Tim

Reformasi Birokrasi Pemerintah Daerah DIY.

DIY dalam angka 2013, BPS DIY.

Profil Ombudsman DIY

Laporan Tahunan LOD DIY tahun 2012.

Laporan Tahunan LOD DIY tahun 2013.

Laporan Tahunan LOD DIY tahun 2014.

www.lod-diy.or.id

www.ombudsman.go.id

www.kompasiana.com 